RENATA DOPIERAŁA*

University of Lodz

DOI: $10.26485 / \mathrm{PS} / 2017 / 66.4 / 4$

\title{
MINIMALISM - A NEW MODE OF CONSUMPTION?
}

\begin{abstract}
This article discusses minimalism as an example of anti-consumer-oriented social practices. The first section focuses on the assumptions of minimalism. The following parts refer to different variants of the relationship between minimalism and derivatives of consumption, i.e. anti-consumption and hyper-consumption (consumerism). The author also considers minimalism as a style of consumption and as a form of conscious consumption. The analysis is based on minimalist blogs and books.

Keywords: minimalism, consumption, consumerism, alternative forms of consumption
\end{abstract}

Minimalism is a lifestyle ${ }^{1}$ that, according to its followers and some researchers, is characterized by an anti-consumerist approach combined with the demand for seeking meaning in life by means other than consumerism-oriented attitudes. Its main principle - "less is more" - is explained as "owning less" in order to achieve more in non-material aspects of life. Such a view of minimalism provides comprehensive instruments for carrying out life changes according to a specific pattern. These include: criticism of consumerism (excessive consumption); post-

* Dr, Faculty of Economics and Sociology, Institute of Sociology, Department of Sociology of Culture; renata_dopierala@poczta.onet.pl

1 This is one of the many definitions of minimalism used primarily by its researchers. Other terms appearing both in texts authored by minimalists themselves and (less frequently) in the secondary literature include: idea, ideology, way of life, philosophy, way of thinking, doctrine, attitude, fashion, and way. 
materialistic redirection of aspirations (discovery of "real" values) and methods of restructuring one's 'old lifestyle' (minimalism as a tool).

The article presents three intertwined issues. Firstly, it distinguishes the most commonly repeated practices making up the minimalist lifestyle. In this context, it refers to various perspectives of minimalism which illustrate the way it is understood (simultaneously, this allows to present its multi-threading). Secondly, it presents an interpretation of the anti-consumption orientation of minimalism; specifying what this turn, if it is real, consists in and how it is manifested. From this standpoint, it is also important to consider the relationship between minimalism and the dominating consumerism paradigm. Thirdly, based on earlier findings the article discusses the social and political potential of minimalism as a phenomenon associated with changes in the capitalist system. The framework for the considerations outlined in this manner is the concept of a consumer society [Baudrillard 2006, Bauman 2009, 2005]. ${ }^{2}$ Due to the widespread general knowledge of its main assumptions, it is not discussed in detail; rather only selected issues, significant for the main thesis of the paper, will be examined. The analysis is based on texts created by minimalists and on scientific discussions of the phenomenon.

\section{MINIMALISM - INTRODUCTION}

The life transformation proposed by minimalism begins with a recognition of what is unnecessary in life and getting rid of, limiting, or reducing reliance on such things. The next step is to identify what is important (this will be different for everyone). The discovery of what is 'excess' in the material sense (the redundancy of goods, objects), as opposed to what is in 'deficit' in the psycho-spiritual aspect seems to be the most important factor. It is difficult to unambiguously determine the difference between a consumption of 'proper size' (moderate?) and excessive consumption - there is no measure that would allow to estimate the exact volumes. It is rather a relative issue, and each individual 'casts the final vote' on what, in his or her opinion, is 'excessive'. The category of "excess", functioning in the concepts of a consumer society, proves useful; in this sense, excessive

2 Zygmunt Bauman [2005: 23-24] writes that: "When we say that ours is a 'consumer society' we must have in mind something more than the trivial, ordinary and not particularly illuminating fact that all members of that society consume (to consume means using things up). (...) The way present-day society shapes its members is dictated first and foremost by the need to play the role of the consumer, and the norm our society holds up to its members is that of the ability and willingness to play it." 
consumption has connotations similar to "superfluity" (excess of goods in relation to the necessities of life). The essence of minimalism is, therefore, a negation of ostentation, of compulsive, mindless purchasing, and a critical analysis of the quantities of objects owned together with the social meaning ascribed to them.

Becoming a minimalist and building and sustaining one's own self-definition is a process. What matters here is a search for moderation and balance (reasonable measure) to be found by each of us individually. Minimalism makes this explorations easier - it is primarily treated as a needed tool to accomplish the goals set by the individual. As emphasised in the posts published by minimalists on blogs and books, everyone understands them differently and chooses individually the corresponding elements and adapts them to their own needs. Minimalism is often combined with vegetarianism (and related variations), ecology, religious and spiritual practices etc., but they do not have to be practiced by every minimalist. Minimalism may correspond to the "zero waste" attitude (this would be a further step towards elimination of nonessential things). There is no contradiction between them - as part of limiting the resources owned, a minimalist may also strive to reduce the waste generated, based on a simple relation: the less I have, and process, the less waste I generate.

"Minimalism is not nor should it ever become a goal in itself, but merely a tool in pursuit of a goal. (...) If we want to lead a simple, wise and harmonious life, we must understand which values are important to us because they lead us through life and everything else comes out of them." (emphasis by the author) [Kędzierska 2016: 21,22]. This instrumental character of minimalism is particularly evident in the definition of Joshua Becker, according to whom it is "the intentional promotion of the things we most value and the removal of everything that distracts us from them" [Becker 2017: 28]. Joshua Fields Millburn and Ryan Nikodemus emphasise use of this tool - "minimalism is a tool to rid yourself of life's excess in favour of focusing on what is important - so you can find happiness, fulfillment, and freedom" [www.theminimalist.com/minimalism]. Important aspects in the declarations of the minimalists include, in addition to the quantitative aspect, the intentionality and voluntariness of actions.

Andrzej Kasperek [2014a, 2014b] sees minimalism as a "second wave", i.e. as a continuation of voluntary simplicity (voluntary simplification of life, simple life, simple living), albeit more trivialized, mostly by the Internet (as the medium in which the messages about it were initially produced). At the same time, he states that it is difficult to clearly indicate a boundary between voluntary simplicity and minimalism; some of its representatives equate these two phenomena and use these terms interchangeably, while others place them in a relational perspective, with 
voluntary simplicity having a broader scope of meaning. Duan Elgin and Arnold Mitchell, the promoters of the Voluntary Simplicity Movement in the United States, embrace a simple life as "materially modest, but emotionally, intellectually and spiritually rich" [Elgin, Mitchell 1977: 5] . They created a set of values that form the core of existence marked by simplicity. These include: a human scale, self-determination, personal growth, ecological awareness, and material simplicity (a key aspect of the minimalist lifestyle) [Elgin, Mitchell 1977: 4]. Voluntary simplicity has a longer history (it reached its popularity in the 1970s), ${ }^{3}$ whereas minimalism became popular after $2008,{ }^{4}$ as a result of the crisis in the capitalist system. However, it is becoming trivialized due to its frequent inclusion in self-help and quasi-therapeutic literature, as well as by an individualist culture that commands individuals to find an "autonomously" designed mode of fulfilment."

Voluntary simplicity, as proposed by Samuel Alexander, is even closer to minimalism and the socio-cultural conditions in which it functions. He claims that: "Voluntary simplicity is an oppositional living strategy that rejects the high-consumption, materialistic lifestyles of consumer cultures and affirms what is often just called "the simple life" or "downshifting". Sometimes called "the quiet revolution", this approach to life involves providing for material needs as simply and directly as possible, minimizing expenditure on consumer goods and services, and directing progressively more time and energy towards pursuing non-materialistic sources of satisfaction and meaning" [Alexander 2011: 6]. The last element is crucial in the context of minimalism; it indicates a change of direction in the selection of consumed goods. Material values are replaced by post-materialist values, associated with the culture of self-expression (such as individualism, autonomy) [Inglehart 1990, 1997].

The studies to date have given rise to the common assumption that minimalism is multidimensional, internally inconsistent, and ephemeral. There is no one canonical version or existing definition of minimalism - each individual creates his/her unique set of beliefs and actions, which differ in their scope and intensity of change.

3 This does not mean that it only appeared then. Its antecedents can be found in ancient philosophy (in Stoicism, Epicureanism), Eastern religions (Buddhism, Taoism), and the views of American transcendentalists (Ralph Waldo Emerson and Henry David Thoreau).

4 Minimalism is not an entirely new phenomenon. This term defines the currents in philosophy, art (mainly literature, painting and architecture) and linguistics.

5 Some of the examples include texts published in Polish within the last three years: Babauta [2014]; Mularczyk-Meyer [2014, 2015]; Kędzierska [2016]; Jay [2016]; Becker [2017]; Sasaki [2017]. 
Minimalism can be seen from several points of view (they do not have to be disjointed), illustrating the complexity of the phenomenon:

1. As an example of an advisory and the therapeutic culture;

2. As a marketing trend, the elements of which are used in different aspects of life;

3. As an illustration of a new anti-consumerist spirituality [see Kasperek 2016];

4. As a style of consumption in which the quantity of possessions is limited, but they are still consumed by choosing products of higher value and quality or by focusing on non-material determinants of existence (experiences, emotions etc.);

5. As an alternative form of satisfying one's needs, which develops practices standing in opposition to excessive consumption.

Let us take a closer look at the last two points of view, which are to some extent mutually contradictory.

\section{MINIMALISM AGAINST ANTI- AND HYPER-CONSUMPTION}

The basic dimension that constitutes minimalism is the attitude towards consumption. Researchers describing and analyzing minimalism define it as an example of an "anti-consumerist protest" [Kasperek 2016] or a reaction to the "overabundance of excessive consumption" [Kramarczyk 2015]. Each of these attitudes illustrates different variants of the relationship between minimalism and consumption and its derivatives: anti-consumption (anti-consumerism) and hyper-consumption (excessive consumption). Let us now consider the links and relationships between them.

One minimalist declares: "It is sometimes said that minimalism is anti-consumerist. It is just as wrong as claiming that minimalists give up on possessions. (...) It is impossible to function normally in society and completely abandon material goods. We earn, we buy, we consume. What should be taken into account is proportion. Minimalists do not give up on consumption but they try to keep it within appropriate and reasonable limits. They reject greed and buying without thinking" [Mularczyk-Meyer 2014: 93]. This voice within the social world of minimalists questions treating it as a "totally" anti-consumption approach, pointing to its more nuanced determinants.

It is fundamental to redefine the approach towards consumption and things, and to give them new meanings. Francine Jay formulates such a mini-manifesto: "Becoming minimalists puts us in control of our stuff. (...) We declare independence from the tyranny of clutter" [Jay 2016: 11]. Therefore, it is about creating a distance from the belief that material goods are the basis for individual identi- 
fication and perception by others. It is also wrong to think that they are determinants of social position and a means of satisfying the need for respect, prestige and recognition. They also should not be equated with gaining happiness and personal fulfilment. Contrary to the dominant consumerist ideology, minimalists declare that they do not concentrate on material objects. They are not interested in possessing, collecting, and accumulating things - they equate this way of life with a lifestyle of material frugality. One may ask: Why does the excess of things have negative aspects for individual identity and life? First of all, a person wastes time on activities connected with items like cleaning, ordering, securing, looking after and taking care of them, and wastes money on buying things owing to social coercion and cultural expectations. Spending most of one's time on earning money can lead to stress and burnout, and interfere with the balance between work and family life. Those who still want more are threatened by indebtedness.

For these reasons minimalism is about changing the status of objects in everyday live -"giving them their proper importance" [Kędzierska 2016: 36], and assigning them different meanings - "Treat them as tools, not goals in themselves" [Mularczyk-Meyer 2014: 56-57]. The attitude towards things presented by the minimalists results from the reversal of their basic characteristics, especially with respect to the consumer culture. But despite the declaration of minimalists that they do not pay attention to objects, they still play a huge role in their life. According to Marek Krajewski [2013: 80] "minimalists continue to be in the possession of things from which they want to liberate"; thus, these things continuously determine the manner of their actions, life goals, and the rules of conduct. Most activities and actions are connected with reflections about things. Paradoxically, while minimalists are identified by their attitude to the (lack of) material objects, such objects are all the time present in their life. As a result, it is crucial to determine the role of objects in the life of a minimalist, the status attached to them, and the perception of relationships with them.

Andrzej Kasperek [2016] considers the focus on things (as a dominant dimension) to be a vulgarized version of minimalism (which undoubtedly includes the media projects which aim to limiting the objects we possess to 100,50 or even less). However, the relation to the material realm is an essential element in the identification of minimalists, and therefore is constitutive of the worldview and lifestyle associated with it. It is the basis for an approach to things that - according to minimalists - shapes a new perspective on our perception not only of ourselves, but also of the socio-cultural reality.

The assumptions of minimalism are in conflict with statements describing the consumer society. As Zygmunt Bauman demonstrates, in the consumer society, 
"it is no coincidence that the pursuit of happiness (...) focuses not on producing things or appropriating (not to mention storing) them, but on throwing them out" [Bauman 2009: 44]; therefore, the dominant activity is collecting things and subsequently getting rid of them or replacing them with other objects. Moreover, happiness is not equated with satisfying needs (even if so, then only temporarily, since the state of insatiability is more functional), but rather with the continuous increase and intensification of desires and aspirations which are to be fulfilled thanks to the products offered (which equally quickly undergo devaluation). Consumption which is motivated by satisfying basic needs is ascribed with - in Bauman's opinion - "primitivism, immaturity, or exaggerated traditionalism (and remaining in a fundamental contradiction with happiness)" [Bauman 2009: 52]. Minimalists, however, use a different vision of "happiness" and the "good life", They do not associate it with participation and competition in consumption. This does not mean that material security does not have any meaning for them; on the contrary it is necessary in order to be a minimalist in the meaning described. Therefore, if one assumes that consumerism is the economy of excess and wastage based on irrationality (and not on calculation), and on creating desires and impulsive whims, then in this sense minimalism is definitely anti-consumerist.

\section{MINIMALISM AS A STYLE OF CONSUMPTION}

The redirection of one's orientations in life towards post-materialistic values justifies the examination of minimalism as an example of a new spirituality [Kasperek 2016, 2014a]. It is characterized not only by individualism, but at the same time by various forms of a non-obligatory sense of community, with emphasis on the temporal, non-religious forms of manifestation and pursuing the well-being of an individual. In relation to minimalism, this spirituality indicates the need for individual growth, internal self-improvement and "raising the consciousness to another level". A specific contradiction arises here. On one hand, Kasperek [2016] recognizes the dependency (or even correspondence) between the characteristics of this new spirituality and the attributes of the consumer society which contributed to its emergence. The growth of a culture of subjective well-being is an element of the "logic" of modern capitalism, which transforms not only experiences and observations, but also spirituality into goods confined within consumer activities, characterized by a decidedly commercial dimension. On the other hand, as the author states: "The essence of the minimalist spirituality is anti-consumerism and without a doubt it should not be treated as a pillar of consumer capitalism. Quite the opposite, the popularization of a simple, mini- 
malist lifestyle would have to lead to questioning the imperatives governing the consumer society" [Kasperek 2016: 79].

One has to ponder whether this notion is justified. The fragments of statements from minimalists given above explicitly indicate the negation of this anti-consumer approach. What they emphasize is their opposition to the excess (excessive possession and consumption) and in turn place the emphasis on quality instead of quantity. Let's summon here another notion by one of the spokesmen of minimalism: "To live is to consume. We all need food and shelter and clothing. We also have passions and purposes that we desire to fulfill. These needs and these purposes require material goods. Minimalism does not reject all material purchases, but it provides the opportunity (and the desire) to own higher-quality items. In a minimalist economy, well-designed, multi-purpose, quality-crafted items will be desired and purchased" [www.becomingminimalist.com/minimalisteconomy]. This high quality concerns multiple possibilities for the usage of items and devices, longer product life (increased durability), with a focus on the materials applied and the way a given item was made. The selection of such products is thus a consumer strategy, standing in opposition to the acquisition of mass-produced, cheap and low quality goods. As Marta Skowrońska notes: "The reduction and selection of items in many cases leads to selection of the most effective, functional, aesthetically pleasing, space-saving and lightest items, which usually denotes high priced products of well-known brands" [Skowrońska 2013: 91]. This confirms the associations between minimalism and the capitalist economy and how the latter is embedded in the minimalist reality.

Interpreted from this standpoint, minimalism depicts (only?) reorientations of individual choices, which fits into the phenomenon of downshifting. In this case, money is still spent, but it is allocated for other types of goods than strictly material ones: travel, tourism, art, which in principle is aimed at providing equally high quality and valuable experiences from the perspective of self-realization of the individual. Equally important and pronounced is the assumption that we have the resources necessary to realize our goals. What's more, these behaviours reflect the characteristics of an advisory and therapeutic culture ${ }^{6}$ [see Jacyno

\footnotetext{
Minimalism promotes activities supporting individuals in dealing with their lives, making decisions and choices which are aimed at improving the quality of life. The range of pieces of advice provided by minimalists is wide and includes: nutrition (eating habits, diets, meal preparation), travelling and moving, management of things (DIY, locality, seasonality), organization of domestic space (amount and type of furniture, arrangement, souvenirs), owned things, objects (what, which, how many?), hygiene (beauty treatments, the use of natural cosmetics), use of technical equipment, leisure activities, personal development (development of passions, interests, time for oneself),
} 
2007]. The exchange of objects - characteristic for this moderate form of minimalism - does not entail a change in their function in the life of an individual [see: Krajewski 2014, Górnik-Durose 2002]. ${ }^{7}$ Their role remains the same, i.e. they are still symbols of consumption. Amitai Etzioni writes: "To those who are wealthy, rejecting the symbols of success is acceptable only so long as you can display the objects of poverty in a way that makes it clear you are just rolling in dough" [Etzioni 1998: 621]. The "poverty" is imaginary in this context; an example of such a strategy is poor chic $^{8}$ [Raciniewska 2013].

Therefore, if the high quality of goods and its primacy over quantity is important, is it not polemical to state that "minimalism is not a turn towards the luxurious" [Kramarczyk 2015: 48]. This aspect is emphasized mainly by the critics of minimalism, who point out that it signifies a form of ostentation. This is illustrated for instance by the "media" minimalist Dominique Loreau, whose attitude is often criticized within the realm of the social world of minimalists. She is a representative of "luxurious" (sublime) minimalism, which is an example of "practices of high status" [see Duda 2013]. This is not directly contradictory to the common mass worldview, but becomes a main factor in defining the social status and determining the prestige of an individual. From this standpoint, the type of "contestation" proposed by minimalism is as equally commercialized as other forms of rebellion, opposition and resistance to dominant practices. As proven by Jean Baudrillard, "sub-consumption" and "inconspicuous consumption" do not manifest themselves through "ostentation" (Veblen's "conspicuous consumption"), but rather through discretion, restraint, and voluntary self-sacrifice, which are nothing else but an additional market, a luxury on a higher plane, an

relationships with others (how to build satisfying relationships and how to separate oneself from others), and education. "Individual experts", people publicly associated with minimalism may play the role of advisers in creating a minimalist, yet good life, including "collectives" - users of blogs, forums dedicated to minimalism, people who formulate recommendations that are useful to others.

7 Małgorzata Górnik-Durose [2002: 73-77] indicates two main functions of things: instrumental and symbolic. Within the first we can distinguish the following "sub-functions": utilitarian, hedonistic, interpersonal, economic (securing) and exploratory (cognitive); and within the second: expressive, sentimental (retrospective) and social (prestigious). At the same time, the author notes that "in terms of the consumption culture, the perspective of needs and their motivational role does not appear to be sufficient to answer the question of why we really need material goods. The analysis of these needs leads to enumerating more categories and creating new classifications, with full awareness that many of these needs can be met without material goods". [Górnik-Durose 2002: 73].

8 Poor chic encompasses a variety of fashions and aesthetics, whose common feature is poverty-like styling, treating poverty as a form of entertainment and referring to symbols identified with low social status and the underclass [Raciniewska 2014: 89 et seq.]. 
expression of even more pronounced conspicuousness, which transforms itself into its antithesis and thus is an even more subtle difference. Therefore, while the differentiation might take the form of renouncing items and "consumption", it still is nothing other than consumption in its purest form" [Baudrillard 2006: 108].

The publicist Chelsea Fagan points out another aspect. Assuming that minimalism is a reaction (or an answer) to the hyper-consumerism of late capitalism, then it would have a distinct "bricolage" feel, corresponding to the individualistic, pluralized and highly psychological character of modern culture, i.e. "minimalism as a secular kind of religion, an add-on to the cultures of yoga and green juices and general living well by putting together a tapas platter of cultural and spiritual practices without ever fully committing to one" [Fagan 2017]. The author considers the call for more conscious and ethical purchases quite poignant, but notes the rare reflections among minimalists on, among other things, issues related to social inequalities (minimalism would thus fit into the neo-liberal vision of social order). This does not signify that themes critical of the consumer society are altogether non-existent in minimalism. They concern the excessive production of objects, manipulative marketing and advertising activities, lack of awareness of the damaging effects of overconsumption, the creation of false needs, exploitation of natural resources and environmental pollution, globalisation, competition rather than cooperation, and the priority given to private property and individual benefits. There is however a distinct lack of deeper diagnoses and complex visions of social change (this is discussed more in later sections of this text). Continuing her deliberations, the author observes that: "Very few of these minimalist troubadours ever really take things to an economic or classbased argument. It's about reducing for personal enlightenment and pompous blog posts; it's not about arguing for a more equitable society in which people consume proportionate to their needs. (If you need a perfect example of this, note the fetishization of the curated "simplicity" of the ultra-rich: their clean loft spaces, their designer capsule wardrobes, their elaborately reduced diets). These people are still conspicuously consuming in mind-boggling ways, they're just filtering it through the convenient prism of simplicity, and that allows their million-dollar wardrobes to somehow be aspirational for someone advocating for "minimalism" [Fagan 2017]. This minimalistic "quasi anti-consumerism" and "quasi anti-materialism" is thus determined by class and is an indicator of high status and a sign of distancing oneself, in accordance with the Baudrillard's depictions of "inconspicuous consumption".

Minimalism is a lifestyle associated mainly with the middle and upper class. Minimalists are usually individuals with an established material and professional 
situation who can afford - having satisfied their vital living needs - to achieve post-materialistic aspirations. Minimalism is, thus, an ideology (according to its critics just another marketing trend) consisting of choosing "not having" and not identifying oneself through material goods. In the case of those in worse material situations (which is not necessarily tantamount to the lower class), it is not a choice but rather a necessity - their limited financial resources force them to take on a limitation-based attitude and search for alternative solutions for satisfying their needs. Therefore, the meaning of 'prosumer practices' and strategies of processing things is different for these groups - they are a non-problematic form of resourcefulness which, in the case of those in a better material situation, is a form of differentiation and, at the same time, a manifestation of their individual disagreement with the rules of the capitalist system.

\section{MINIMALISM AS A FORM OF CONSCIOUS CONSUMPTION}

As was stated earlier "minimalism is not a full retreat from consumerism or an anti-consumption behavior, but rather a form of a conscious choice, which helps the individual to achieve balance and better quality in the everyday life" [Kramarczyk 2015: 283]. So it is worthwhile asking: What beliefs and actions constitute this conscious attitude towards consumption?

It is based mainly on restricting and reducing the excessive amount of gathered goods ("inventory" lists can be helpful) and subsequent reflection on purchases (e.g. by asking oneself the following question: "Do I really need this?"). The goal is to possess necessary things which are actually utilized, and to skilfully manage such items. It is necessary to discard items which are unused, unhelpful, or non-functional, and retain only those things which are necessary, beneficial and memorable. There are various strategies intended to gain and maintain this control: donating the unnecessary items to individuals or institutions in need; selling them (e.g. via the Internet); exchanging with others (for example mutual borrowing of rarely used devices that are not needed at home); replacing old things with new things (in the sense of eliminating, for example, two older things by one new item); evaluating their usefulness (do we really need this device? can we replace it?); utilizing used items; fixing things (individually or using local services); not wasting things (especially food); and not attaching oneself to things.

Examined from this perspective, minimalism fits into the cooperative economy, which changes the processes of organization and distribution of products towards the creation of networks of individuals and communities which provide mutual services, and co-create and share goods. Such an economy is based on 
values and motivations declared as important for minimalists: helping others and sharing our time and resources, which can be reciprocated in either a material or non-material way. In this economic model, competition between producers is supplanted by cooperation between prosumers and consumers. Its growth became possible thanks to new technologies ensuring the creation of horizontal, direct relations, offering numerous platforms making it possible to link tenderers with purchasers without the participation of a third-party or central organization. Similarly as in the case of minimalism, the popularization of economy of cooperation was fuelled by the financial crisis in 2008 (which contributed to the necessity to restrict expenses, better usage of resources, and changes in social relations).

The economy of cooperation (also known as the sharing economy or collaborative economy) is based on the notion that "access is better than ownership." It is based on notions strictly corresponding with the views of minimalists on the role of possessions in our everyday life - individuals do not want to, do not have to, or cannot afford to have all the items, many of which are not used by them. This principle is applied especially to situations where possession: is not treated as an autotelic value (i.e. status is not built on its basis, or there is no sentimental value attached to items), but instead treated as a means to attain goals (this concerns, for example, equipment used to make renovations); or where being in possession of an item exceeds the financial capabilities of an individual; or it is not economically justified (we use something very rarely); or the usage of an item is associated with large maintenance costs and is time consuming. This form of economy is an alternative to the "reduce, reuse, recycle, and repair" principle.

A reflective approach to consumption assumes saving time and money (restriction of unnecessary expenses, thoughtful and planned purchases of what is needed at the moment, not undertaking excessive financial obligations), buying local and seasonal items, paying attention to products' composition, their origin and execution (a high importance is attributed to durability and reliability). Such activities are characteristic not only of minimalists - they are also associated with the level of wealth of an individual and his or her social level. In societies located higher on the prosperity scale, it is not so much the (low) price which ultimately determines consumer choices, but most of all other (quality) parameters of the offered goods.

The phenomenon of conscious consumption, together with a form of resistance towards dominant consumer behaviors, is also supporting the movement towards indigenous and local manufacturing, searching for information regarding the structure of ownership of companies and their "reputation", avoiding (often 
ignoring) the products of global corporations. Another factor intertwined with the minimalist way of life and consumption is the differentiation between needs (real and specific) and whims and impulses, which individuals should restrict and ultimately eliminate (they distract and prevent the achievement of the desired mindfulness). Prosumption, that is individually producing and fulfilling needs and where possible avoiding paid services, e.g. in the preparation of products, baking bread, vegetable growing, embroidery, knitting, sewing of clothes etc. is popular among minimalists. The narrative interviews conducted by Justyna Kramarczyk suggest that the obtained goods, beside having pragmatic and identity values (a feeling of agency, satisfaction, and an opportunity for self-realization) are a "guarantee that the whole process of creating a product proceeded in accordance with defined and usually known criteria and also that the final product is more personalized in terms of consumer expectations" [Kramarczyk 2015: 282]. This statement may be seen as a confirmation of the class determinant of minimalist practices - another form of differentiation, but also the individualization of consumer activities ("personalization"). As a result of the sharing economy, it is possible to make incidental or even more permanent contacts, e.g. neighborly contacts, within the scope of cooperatives which allow for the exchange of "nonmarket" goods and services. Naturally, the popularity of hand-made products [see Olechnicki 2017] is not a sole domain of minimalists; however in their case it coincides with the worldview which they propagate (combined or reinforced by, for example, an interest in ecology).

\section{THE SOCIAL AND POLITICAL POTENTIAL OF MINIMALISM}

In describing minimalism as a "spirituality of inner peace" Kasperek [2016] recognizes that besides "the search for inner balance" a mode of social life is also involved, in which "cooperation, compassion, and kindness are propagated and there is no place for competition, which is the driving force of the consumer capitalism" [Kasperek 2016: 79]. Thus we can ask the following questions: Does minimalism offer an alternative vision of social organization? Can the emphasis on post-materialistic attitudes be the foundation of a new axio-normative order? And is it conducive to building community and establishing strong social bonds based on the aforementioned values?

In this regard, one should refer to the concept of voluntary simplicity, which shares some things in common with minimalism. Some of the researchers of the Voluntary Simplicity Movement perceive it as an alternative to the alienation tendencies of the modern world. This results from the significance that can 
be assigned to relationships with others, involvement in political issues, and a greater sensitivity to social issues. But even in this case discrepancies can be noted. Critics point out the way voluntary simplicity separates individuals from the society, arguing that too much emphasis is put on the individual and his or her closest circle, and therefore the movement can be considered not only isolating but also apolitical. Thus, there is no simple transference from the level of strong primordial relationships to ones defined by more community and association-based characteristics. Let us take a closer look at the writings of one of the enthusiasts of the simple life on the 'common good' as an element of the "minimalist economy": "This represents the greatest benefit of minimalism on the macro-level. Minimalism provides an opportunity for the individual to practice generosity on a larger scale than ever before. Minimalism allows us to redirect our finite resources away from our wants and begin to use them in practical ways to meet other people's needs. Whether we are feeding the hungry, housing the orphan, saving the environment, protecting animals, or speaking up for the disenfranchised, our resources can make this world a better place for everybody" [www.becomingminimalist.com/minimalist-economy]. Without doubt the dominant feature of this statement is the utopian nature of the outlined vision, not taking into account the economic, political, and cultural conditions which determine the capitalist social system. In addition, the individualistic approach is quite vivid, which is rather contradictory to the proposed community-oriented approach of individual actions. In another excerpt the author directly indicates that lowering the amount of money allocated for buying items and the time devoted to engaging with them allows us to take care of our own health, mental well-being, and productivity. It should be noted that some critics argue that voluntary simplicity offers a narrow hedonism, as it is reserved for a small number of privileged individuals and, due to its very nature, is professed and practiced mainly by those who can easily regulate the material levels of their lives.

Mary Grigsby observes that the members of the voluntary simplicity movement "rarely undertake political initiatives, instead focusing mainly on individual actions as the main mechanism of change" [Grigsby 2004: 9]. Their demands, which largely concern criticism of the capitalist system, could be implemented but would require the politicization of their actions. This indicates that the efforts to reform the system cannot be restricted to individual transformations. There is a need to include grass-roots and bottom up mechanisms to change topdown policies. The question thus arises: Is it even possible to talk about a social movement within the context of the simple life? According to the Grigsby, it is 
at most a "loosely connected" movement, characterized more by cultural than social aspects.

Grigsby's diagnosis also concerns minimalism. It can be problematic to define it in terms of a social movement, but at the same time one of the characteristics of the new social movements, which can be also traced to minimalist practices, should be noted. This characteristic is the constant blurring of the line between the public role and the private role. By overlapping and intermingling the two dimensions, a specific form of subculture is born [Della Porta, Diani 2009]. There is no distinction between actions for the universal, common good and the self-realization sphere (purchase of goods at local retailers not only restricts the revenue of corporations but also builds individual and social identity). The question which remains is whether and to what degree the aforementioned actions might lead to a real change of the social system. They result - at least in the subjective opinion - in gaining independence from the market and corporations, and in care for the environment and sustainable development (local actions emerge as an alternative to neoliberal, globalisation patterns). These attitudes do not downplay the importance of market mechanisms in general; products of natural origin and ecological products are, after all, subject to the same economic laws as other products.

\section{CONCLUSIONS}

It is safe to assume that minimalism is characterized by ambivalence. On one hand it is a negation of hyper-consumption - "Minimalism is the opposite of excess, namely wastage" [Kędzierska 2016: 52], "It is not about a revolution nor sacrifices, but rationalizing the state of our assets and the level of consumption" [Mularczyk-Meyer 2014: 64]. On the other hand it remains in the realm of consumer logic, with the vector shifting towards high quality goods, experiences, and sensations. It is at the same time a "distinction in the world of excess, but also a strategy for the time of crisis" [Skowrońska 2013: 90]. Minimalism is varied and multifaceted. For some, it is a superficial, fleeting fad, while for others it is a form of distinctive consumer behaviour, and for a specific part of population it constitutes an internalized system of beliefs embedded in the values of voluntary simplicity. By referencing the phraseology applied in minimalism we can define it as a multifunctional tool, which is useful in modern, complex societies. 


\section{REFERENCES}

Alexander Samuel. 2011. "The voluntary simplicity movement. Reimagining the good life beyond consumer culture". The International Journal of Environmental, Cultural, Economic and Social Sustainability 7: 4-21.

Babauta Leo. 2014. Książeczka minimalisty. Prosty przewodnik szczęśliwego człowieka. Gliwice: Wydawnictwo Helion.

Baudrillard Jean. 2006. Społeczeństwo konsumpcyjne. Jego mity i struktury. Warszawa: Wydawnictwo Sic!

Bauman Zygmunt. 2009. Konsumowanie życia. Kraków: Wydawnictwo Uniwersytetu Jagiellońskiego.

Bauman Zygmunt. 2005. Work, consumerism and the new poor. Buckingham: Open University Press.

Becker Joshua. 2017. Im mniej, tym więcej. Kraków: Wydawnictwo Znak.

Becker Joshua. Minimalist economy. www.becomingminimalist.com [dostęp: 17.06.2017]

Della Porta Donatella. 2009. Ruchy społeczne. Wprowadzenie. Kraków: Wydawnictwo Uniwersytetu Jagiellońskiego.

Duda Aneta. 2013. „Strategie oporu konsumenckiego - dezercja z rynku czy współpraca”. Kultura i Spoleczeństwo 4: 49-68.

Elgin Duan, Arnold Mitchell. 1977. "Voluntary simplicity". The Co-Evolution Qarterly (Summer) 4-19.

Elgin Duan. Voluntary simplicity. Toward a way of life that is outwardly simple, inwardly rich, Second Revised Edition, New York 2010.

Etzioni Amitai. 1998. „Voluntary simplicity. Characterization, select, psychological implications and social consequences". Journal of Economic Psychology 19: 619-643.

Fagan Chelsea. 2017. „Minimalism. Another boring product wealthy people can buy”. The Guardian, 3 March 2017. www.theguardian.com/lifeandstyle/2017/mar/04/minimalismconspicuous-consumption-class [dostęp 15.09.2017]

Górnik-Durose Malgorzata. 2002. Psychologiczne aspekty posiadania - między instrumentalnościa a społeczną użytecznościa dóbr materialnych. Katowice: Wydawnictwo Uniwersytetu Śląskiego.

Grigsby Mary. 2004. Buying time and getting by: the voluntary simplicity movement, New York: Albany.

Inglehart Ronald. 1997. Modernization and postmodernization. Cultural, economic and political change in 43 societies. New York: Princeton University Press.

Inglehart Ronald. 1990. Culture shift in advanced industrial societies. New York: Princeton University Press.

Jacyno Malgorzata. 2007. Kultura indywidualizmu. Warszawa: Wydawnictwo Naukowe PWN. Jay Francine. 2016. Minimalizm daje radość. Warszawa: Muza SA.

Kasperek Andrzej. 2016. „Minimalistyczna duchowość jako przykład antykonsumpcjonistycznej duchowości. Perspektywa socjologiczna”. Zeszyty Naukowe KUL 4: 71-88.

Kasperek Andrzej. 2014a. „Wyrażanie sprzeciwu poprzez duchowość. Przypadek minimalizmu". Stan Rzeczy 2: 179-197.

Kasperek Andrzej. 2014b. „Minimalistów poszukiwania wewnętrznego spokoju”. Fragile 3-4: $6-11$.

Kędzierska Katarzyna. 2016. Chcieć mniej. Minimalizm w praktyce. Kraków: Znak Litera Nova. 
Krajewski Marek. 2013. Sa w życiu rzeczy... Szkice z socjologii przedmiotów. Warszawa: Fundacja Nowej Kultury Bęc Zmiana.

Kramarczyk Justyna. 2015. „Mieć czy być? Minimalizm jako przykład świadomej konsumpcji w świetle badań własnych". Prace naukowe Uniwersytetu Ekonomicznego we Wrocławiu Konsumpcja jako forma komunikacji społecznej. Nowe paradygmaty i konteksty badawcze 414: 270-285.

Loreau Dominique. 2011. Sztuka prostoty. Warszawa: Wydawnictwo Czarna Owca.

Millburn Joshua Fields, Ryan Nikodemus. Minimalism. www.theminimalist.com [dostęp: 21.06.2017]

Mularczyk-Meyer Anna. 2015. Minimalizm dla zaawansowanych. Wołowiec: Black Publishing.

Mularczyk-Meyer Anna. 2014. Minimalizm po polsku, czyli jak uczynić życie prostszym. Wołowiec: Black Publishing.

Olechnicki Krzysztof. 2017. Subświaty. Na wyspach odczepionych znaczeń. W: Nowe praktyki kulturowe Polaków, T. Szlendak, K. Olechnicki (red.), 221-308. Warszawa: Wydawnictwo Naukowe PWN.

Raciniewska Alicja. 2013. "Poor chic. Estetyka ubóstwa w modzie epoki postindustrialnej". Kultura i Społeczeństwo 4: 83-100.

Sasaki Fumio. 2017. Pożegnanie z nadmiarem. Minimalizm japoński. Warszawa: Wydawnictwo Burda NG Polska.

Skowrońska Marta. 2013. „Minimalizm i chomikowanie: jak radzić sobie z nadmiarem przedmiotów?". Kultura Współczesna 1: 89-104.

Renata Dopierata

\section{MINIMALIZM - NOWY STYL KONSUMPCJI?}

\section{Streszczenie}

W artykule omówiono minimalizm jako przykład antykonsumpcjonistycznie zorientowanych praktyk społecznych. W pierwszej części autor prezentuje główne założenia minimalizmu. W kolejnych punktach analizuje różne warianty relacji między minimalizmem a pochodnymi konsumpcji: antykonsumpcją i hiperkonsumpcją. Autor rozważa również minimalizm jako styl dyskretnej konsumpcji oraz jako formę świadomej konsumpcji. Podstawą analiz są książki i blogi pisane przez minimalistów.

Słowa kluczowe: minimalizm, konsumpcja, konsumeryzm, alternatywne formy konsumpcji 